\title{
PENINGKATAN KEMAMPUAN BERPIKIR KREATIF DALAM MEMECAHKAN MASALAH MATEMATIKA MELALUI MODEL OPEN ENDED LEARNING PADA SISWA KELAS V SD NEGERI SENDANGDALEM TAHUN AJARAN 2017/2018
}

\author{
Endah Puspitaningtyas ${ }^{1}$, Kartika Chrysti Suryandari ${ }^{2}$, Ratna Hidayah ${ }^{3}$ \\ 1,2,3Universitas Sebelas Maret \\ endahpuspita225@gmail.com
}

Article History

accepted 01/06/2019

approved 01/07/2019

published 01/08/2019

\begin{abstract}
The purpose of this research is to improve the ability of creative thinking in solving problems through the application of Open Ended Learning model. This research is a collaborative action research (PTK) conducted in three cycles. The subjects of this study were teachers and students of grade $V$ of SD Negeri Sendangdalem which amounted to 26 students. Data collection techniques used tests, observations, interviews, and questionnaires. Data validity test using triangulation technique. Data analysis used is qualitative data analysis and quantitative data analysis. The results of this study indicate that the implementation of the Open Ended Learning model can increase the ability of creative thinking in solving problems in students in the subjects of $V$ grade mathematics.
\end{abstract}

Keywords: open ended learning, creative thinking, mathematic

\section{Abstrak}

Tujuan penelitian ini yaitu untuk meningkatkan kemampuan berpikir kreatif dalam memecahkan masalah melalui penerapan model Open Ended Learning. Penelitian ini merupakan penelitian tindakan kelas (PTK) kolaboratif yang dilaksanakan dalam tiga siklus. Subjek penelitian ini adalah guru dan siswa kelas V SD Negeri Sendangdalem yang berjumlah 26 siswa. Teknik pengumpulan data menggunakan tes, observasi, wawancara, dan angket. Uji validitas data menggunakan teknik triangulasi. Analisis data yang digunakan adalah teknik analisis data kualitatif dan analisis data kuantitatif. Hasil penelitian ini menunjukkan bahwa penerapan model Open Ended Learning dapat meningkatkan kemampuan berpikir kreatif dalam memecahkan masalah Matematika pada siswa dalam mata pelajaran Matematika kelas $\mathrm{V}$ diketahui dari penelitian yang menunjukkan bahwa persentase siswa pada siklus I mencapai 70,9\%, siklus II mencapai $80,41 \%$, dan siklus III mencapai $85,38 \%$. Hasil penelitian tindakan kelas ini dapat dijadikan sebagai pertimbangan bagi guru untuk meningkatkan kemampuan berpikir kreatif siswa dalam memecahkan masalah Matematika

Kata kunci: open ended learning, berpikir kreatif, matematika 


\section{PENDAHULUAN}

Salah satu wujud usaha pemerintah dalam menghadapi tuntutan abad ke-21 dibidang pendidikan yaitu merumuskan pembelajaran abad 21 yang menekankan pada kompetensi berpikir kritis dan penyelesaian masalah, kreativitas dan inovasi, komunikasi, dan kolaborasi (Kemendikbud, 2017: 5). Kompetensi ini diistilahkan dengan 4C (Creativity, Critical thingking, Comunicative, dan Collaborative). Sejalan dengan hal tersebut, Kemendikbud (2017: 4) memaparkan Matematika yang termasuk salah satu mata pelajaran di Sekolah Dasar diarahkan untuk menekankan pembelajaran sebagai berikut: (1) mendorong siswa mencari tahu berbagai sumber; (2) mampu merumuskan masalah; (3) melatih siswa berpikir logis dan kreatif bukan sekedar berpikir mekanistik; dan (4) mampu bekerja sama dan berkolaborasi dalam menyelesaikan masalah.

Berdasarkan pemaparan di atas, berpikir kreatif menjadi salah satu kompetensi yang penting untuk dimiliki oleh peserta didik. Menurut Career Center Maine Departmen of Labor USA, kemampuan berpikir kreatif memang penting karena kemampuan ini merupakan salah satu kemampuan yang dikehendaki dunia kerja (Mahmudi, 2010).

Menurut Mursidik, Samsiyah, dan Rudyanto (2015) mengemukakan bahwa kompetensi berpikir kreatif bersifat divergen dan menuntut aktivitas investigasi masalah Matematika dari berbagai perspektif, karena melalui investigasi siswa dapat mengoptimalkan pengetahuannya untuk menyelesaikan berbagai permasalahan. Torrance (Fridel dan Rudd, 2006) mengemukakan aspek yang perlu diukur dalam kemampuan berpikir kreatif antara lain:

1. Kelancaran (fluency), yaitu kemampuan untuk menghasilkan banyak gagasan

2. Keluwesan (flexibility), yaitu kemampuan untuk menghasilkan gagasan bervariasi

3. Keaslian (originality), yaitu kemampuan untuk menemukan ide-ide baru untuk memecahkan masalah

4. Elaborasi (elaboration), yaitu kemampuan untuk memcahkan masalah secara detail

Menurut Sitanggang (2010), pembelajaran Matematika sebaiknya dapat mengembangkan kegiatan kreatif dan pola pikir Matematika siswa melalui pemecahan masalah. Namun berdasarkan hasil observasi pada pembelajaran Matematika Kelas $\mathrm{V}$ SD Negeri Sendangdalem Kecamatan Padureso Kabupaten Kebumen pada tanggal 4 November 2017 menunjukkan bahwa kemampuan berpikir kreatif siswa dalam memecahkan masalah masih rendah. Hal ini dapat diamati ketika pembelajaran berlangsung, yaitu: (1) siswa masih memikirkan satu jawaban; (2) siswa kurang menyampaikan berbagai ide dari pertanyaan yang diberikan; (3) siswa masih terpaku pada cara guru dalam memberikan jawaban; (4) siswa belum mampu merinci jawaban dalam penyelesaian masalah.

Kemampuan berpikir kreatif dalam memecahkan masalah pada siswa perlu ditingkatkan menggunakan model pembelajaran yang tepat. Model Open Ended Learning adalah model yang menyajikan permasalahan dengan pemecahan berbagai cara (flexibility) dan solusi juga beragam (fluency) yang dapat menumbuhkan orisinalitas ide, kreativitas, kognitif tinggi, kritis, komunikasi-interaksi, sharing, keterbukaan dan sosialisasi (Shoimin, 2014:109). Sawada mengemukakan bahwa model Open Ended Learning memiliki karakteristik yaitu masalah yang diberikan adalah masalah yang bersifat terbuka (open-ended problem). Dasar keterbukaan masalah diklasifikasikan dalam tiga tipe, yakni:

1. Prosesnya terbuka, maksudnya masalah itu memiliki banyak cara penyelesaian yang benar 
2. Hasil akhirnya terbuka, maksudnya masalah itu memiliki banyak jawaban yang benar

3. Cara pengembangan lanjutannya terbuka, maksudnya ketika siswa telah menyelesaikan masalahnya, mereka dapat mengembangkan masalah baru yaitu dengan cara merubah kondisi masalah sebelumnya (Fatah dkk, 2016)

Kegiatan pembelajaran dengan model Open Ended Learning yang memberikan masalah terbuka akan membawa siswa dalam menjawab permasalahan dengan banyak cara dan juga mungkin banyak jawaban yang benar sehingga mengundang kemampuan berpikir kreatif siswa dalam proses menemukan sesuatu yang baru.

Penerapan model Open Ended Learning menurut Murni (2010) yaitu: (1) orientasi, (2) penyajian masalah terbuka, (3) pengerjaan masalah secara individu, (4) diskusi kelompok tentang masalah terbuka, (5) presentasi hasil diskusi, (6) penutup.

Berdasarkan uraian di atas, peneliti melaksanakan penerapan model Open Ended Learning untuk meningkatkan kemampuan berpikir kreatif dalam memecahkan masalah pada siswa kelas V SD Negeri Sendangdalem tahun ajaran 2017/2018.

Tujuan penelitian ini adalah untuk mengingkatkan kemampuan berpikir kreatif dalam memecahkan masalah Matematika pada siswa kelas V SD Negeri Sendangdalem tahun ajaran 2017/2018.

\section{METODE}

Penelitian ini merupakan penelitian tindakan kelas kolaboratif antara peneliti dengan guru kelas $\mathrm{V}$ di SD Negeri Sendangdalem. Subjek penelitian ini adalah guru dan siswa kelas $\mathrm{V}$ yang berjumlah 26 siswa. Sumber data dalam penelitian ini yaitu guru dan siswa kelas V. Teknik pengumpulan data menggunakan observasi, wawancara, angket, dan tes. Uji validitas data menggunakan triangulasi teknik dan sumber. Analisis data meliputi reduksi data, penyajian data, dan kesimpulan sesuai model analisis data menurut Miles dan Huberman (Sugiyono, 2012: 246-253).

Indikator kinerja penelitian ini adalah peningkatan kemampuan berpikir kreatif dalam memecahkan masalah pada siswa dalam mata pelajaran Matematika dengan ketercapaian target $85 \%$. Penelitian ini memodifikasi prosedur penelitian Kemmis dan Taggart (Arikunto, 2013: 137), yaitu terdiri dari tahap perencanaan, pelaksanaan, pengamatan, dan refleksi.

\section{HASIL DAN PEMBAHASAN}

Penelitian ini dilaksanakan selama tiga siklus dengan menerapkan enam langkah model Open Ended Learning, yaitu (1) orientasi, (2) penyajian masalah terbuka, (3) pengerjaan masalah secara individu, (4) diskusi kelompok tentang masalah terbuka, (5) presentasi hasil diskusi, (6) penutup.

Hasil pengamatan kemampuan berpikir kreatif dalam memecahkan masalah pada siswa dalam mata pelajaran Matematika dinyatakan berhasil. Hal ini dilihat dari peningkatan pencapaian aspek berpikir kreatif. Pertama, kelancaran (fluency) memberikan lebih dari satu jawaban dakam memecahkan masalah tentang kesebangunan dan simetri. Kedua, keluwesan (flexibility), dalam memberikan gagasan dari sudut pandang berbeda dalam memecahkan masalah tentang kesebangunan dan simetri. Ketiga, berpikir orisinil (originality) menemukan gagasan yang berbeda dari orang lain dalam memecahkan masalah tentang kesebangunan dan simetri. Keempat, kemampuan memerinci (elaboration) dalam memecahkan masalah tentang kesebangunan dan simetri. Peningkatan kemampuan berpikir kreatif siswa dalam memecahkan masalah Matematika dapat dilihat pada tabel 1 berikut. 
Tabel 1. Hasil observasi kemampuan berpikir kreatif siswa

\begin{tabular}{llll}
\hline \multirow{4}{*}{ Aspek } & \multicolumn{3}{l}{ Siklus (\%) } \\
\cline { 2 - 4 } & $\mathbf{1}$ & $\mathbf{2}$ & $\mathbf{3}$ \\
\hline Fluency & 81,73 & 86,64 & 89,1 \\
Flexibility & 62,54 & 78,95 & 88,78 \\
Originality & 65,39 & 78,97 & 79,04 \\
Elaboration & 73,94 & 80,8 & 84,62 \\
\hline Rata-rata & $\mathbf{7 0 , 9}$ & $\mathbf{8 1 , 3 4}$ & $\mathbf{8 5 , 3 8}$ \\
\hline
\end{tabular}

Hasil observasi kemampuan berpikir kreatif siswa dalam memecahkan masalah Matematika mengalami peningkatan pada setiap siklus dilihat dari persentase siswa yang memenuhi ketercapain target pada siklus I 70,9\%, siklus II mencapai $81,34 \%$, dan siklus III mencapai $85,38 \%$. Hasil observasi tersebut diperkuat dengan hasil kemampuan berpikir kreatif dalam memecahkan masalah Matematika yang mengalami peningkatan. Berikut persentase ketuntasan siswa yang memenuhi $\mathrm{KKM}=70$ dapat dilihat pada tabel 2.

Tabel 2. Hasil Kemampuan Berpikir Kreatif yang memenuhi ketuntasan

\begin{tabular}{ccc}
\hline Siklus & $\begin{array}{c}\text { Belum } \\
\text { Tuntas (\%) }\end{array}$ & Tuntas (\%) \\
\hline I & $34,62 \%$ & $65,38 \%$ \\
\hline II & $19,24 \%$ & $80,76 \%$ \\
\hline III & $11,54 \%$ & $88,46 \%$ \\
\hline
\end{tabular}

Berdasarkan tabel 2, dapat diketahui siswa yang mengalami ketuntasan pada siklus I sebanyak $65,38 \%$, pada siklus II meningkat $80,76 \%$, dan siklus III mencapai $88,46 \%$. Hal tersebut menunjukkan bahwa ketuntasan siswa sudah mencapai indikator kinerja $85 \%$.

Dengan demikian penerapan model Open Ended Learning dapat meningkatkan kemampuan berpikir kreatif dalam memecahkan masalah pada siswa dilihat dari persentase siswa yang memenuhi ketercapaian target dari siklus I-III. Penggunaan model Open Ended Learning memberikan kesempatan pada siswa untuk melakukan investigasi masalah matematika sehingga dapat mengontruksi segala kemungkinan pemecahannya secara kreatif dan terlibat aktif dalam pembelajaran. Hasil penelitian ini diperkuat dengan penelitan yang dilakukan Fatah, dkk, (2016) bahwa model Open Ended Learning dapat memberikan kesempatan kepada siswa untuk memperoleh pengetahuan/ pengalaman, menemukan, mengenali dan memecahkan masalah dalam beberapa metode dan solusi yang menjadikan siswa yang lebih kreatif dalam penyelesaian masalah. 


\section{SIMPULAN}

Penerapan model Open Ended Learning dapat meningkatkan kemampuan berpikir kreatif dalam memecahkan masalah Matematika pada siswa kelas V SD Negeri Sendangdalem Tahun ajaran 2017/2018, dibuktikan dengan peningkatan persentase siswa yang memenuhi ketercapaian target berpikir kreatif dalam memecahkan masalah sebanyak $85 \%$.

\section{DAFTAR PUSTAKA}

Arikunto, S. (2013). Prosedur Penelitian: Suatu Pendekatan Praktik. Jakarta: Rineka Cipta.

Fatah, A., dkk. (2016). Open-Ended Approach: An Effort In Cultivating Students' Mathematical Creative Thinking Ability And Self-Esteem In Mathematics. Jounal on Mathematical Education. 7 (1) 11

Friedel, C.R \& Rudd, R.D. (2006). Creative Thinking and Learning Styles in Undergraduade Agriculture Students. Jounal Agricultural Education. 47 (4) 103-104

Kemendikbud. (2017a). Materi Umum SD. Jakarta: Direktorat Pembinaan Sekolah Dasar

Kemendikbud. (2017b). Materi Pokok SD. Jakarta: Direktorat Pembinaan Sekolah Dasar

Mahmudi, A. (2010). Mengukur Kemampuan Berpikir Kreatif Matematis. Makalah Konferensi Nasional Matematika XV: Universitas Negeri Yogyakarta

Mursidik, E., Syamsiyah, N., \& Rudyanto, H.E. (2015). Kemampuan Berpikir Kreatif Dalam Memecahkan Masalah Matematika Open-Ended Ditinjau Dari Tingkat Kemampuan Matematika Pada Siswa Sekolah Dasar. Jurnal Pedagogia.4 (1) 23-34

Shoimin, A. (2014). 68 Model Pembelajaran Inovatif dalam Kurikulum 2013. Yogyakarta: Ar-Ruzz Media

Sugiyono. (2012). Metode Penelitian Pendidikan (Pendekatan Kuantitatif, Kualitatif, dan $R \& D)$. Bandung: Penerbit Alfabeta. 